\title{
New Aldose Reductase Inhibitors N99-596 A and B from Streptomyces
}

\author{
Yuesheng Dong, Junshan Yang, Xiao Ren, Hua Zhang, Jiangong He
}

Received: September 26, 2005 / Accepted: October 26, 2005

(C) Japan Antibiotics Research Association

\begin{abstract}
The actinomycete Streptomyces diannanensis, isolated from a soil sample collected in Yunnan province, China, was found to produce two novel isoflavone rhamnopyranosides, namely, 7,4'-dihydroxyisoflavone $3^{\prime}$ - $O-\alpha$-L-rhamnopyranoside (1) and 5,7,4'trihydroxyisoflavone $3^{\prime}-O-\alpha$-L-rhamnopyranoside (2). The structures of $\mathbf{1}$ and $\mathbf{2}$ were elucidated on the basis of extensive 1D and 2D NMR and MS spectral analyses. Compounds 1 and $\mathbf{2}$ exhibited in vitro activities against aldose reductase with an $\mathrm{IC}_{50}$ of 170 and $165 \mu \mathrm{M}$, respectively.
\end{abstract}

Keywords aldose reductase, inhibitor, isoflavone rhamnopyranosides

The sorbitol pathway appears to be involved in metabolism of the excess glucose in diabetic tissues. This may lead to development of some of these complications. Aldose reductase (AR), an enzyme in the polyol pathway, catalyzes the reduction of glucose to sorbitol. Many AR inhibitors have been isolated from microorganisms [1 3]. The clinical efficacy of certain AR inhibitors such as epalrestat has been reported [4,5]. In the course of our screening program for aldose reductase inhibitors, two new isoflavonoids N99-596A (1) and B (2) were found in the fermentation broth of an actinomycete strain N99-596, which was identified as a new actinomycete species named Streptomyces diannanensis. This paper reports the basic taxonomy and fermentation of the strain N99-596 and the isolation, biological properties and structure elucidation of 1 and 2.

Strain N99-596 was isolated from a soil sample collected at Diannan in Yunnan Province, China. The culture of N99596 was characterized by the gray aerial mycelium and the spiral spore chains with whole cell hydrolysate containing LL-diaminopimelic acid, which is of Type I. Strain N99-596 was concluded to be a new actinomycete species based on chemotaxonomy and molecular biology (The result will be reported elsewhere). The strain was deposited in China General Microbiological Culture Collection, Beijing, China, under the name of Streptomyces diannanensis and the accession number is CGMCC No. 0834.

Strain N99-596 was cultivated at $27^{\circ} \mathrm{C}$ on a rotary shaker at $220 \mathrm{rpm}$ in the medium consisting of soluble starch $4.0 \%$, soybean meal $2.0 \%, \mathrm{Na}_{2} \mathrm{~S}_{2} \mathrm{O}_{3}$ solution $(0.1 \mathrm{~mol} / \mathrm{liter})$ $32 \mu \mathrm{l} /$ liter, $\mathrm{FeSO}_{4} \cdot 7 \mathrm{H}_{2} \mathrm{O} 0.05 \%, \mathrm{~K}_{2} \mathrm{HPO}_{4} 0.05 \%, \mathrm{KCl}$ $0.03 \%$ in water ( $\mathrm{pH} 6.5$ ). After fermentation for 6 days, the cultured broth (5.6 liters) was centrifuged to separate mycelial cake and supernatant. The mycelial cake was extracted with acetone (2.0 liters). The acetone solution was filtered and evaporated to remove acetone, and then extracted with ethyl acetate ( 2.5 liters). The ethyl acetate layer was evaporated to give $2.2 \mathrm{~g}$ of crude extract. This extract was subjected to a silica gel column and eluted with chloroform-methanol. The active fractions showing
J. Yang (Corresponding author), Y. Dong: Institute of Medicinal Plant Development, Chinese Academy of Medical Sciences and Peking Union Medical College, Beijing 100094, People's Republic of China, E-mail: jsyang2005@yahoo.com.cn
Y. Dong, X. Ren, H. Zhang, J. He: New Drug Research and Development Center, North China Pharmaceutical Group Corporation and National Microbial Medicine Engineering and Research Center, Shijiazhuang 050015, People's Republic of China 
inhibitory activity against AR were collected and evaporated to give $85.2 \mathrm{mg}$ of a residue. The residue was separated by HPLC using a reverse phase column (Phenomenex PRODIGY $10 \mu$-Prep, $250 \times 20 \mathrm{~mm}$ i.d.), and a solvent of $30 \%$ acetonitrile/water with a flow rate of $6 \mathrm{ml} / \mathrm{minute}$ at a room temperature. The eluates were monitored with a photodiode array detector at $254 \mathrm{~nm}$.

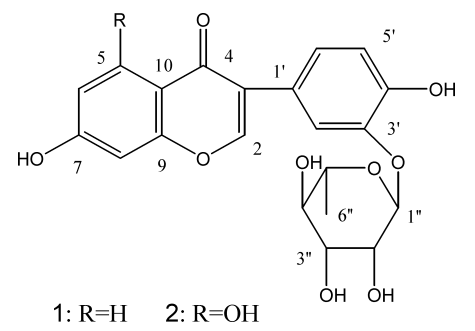

Fig. $\mathbf{1}$ Structures of compounds $\mathbf{1}$ and $\mathbf{2}$ from Streptomyces diannanensis.
Compounds $\mathbf{1}$ and $\mathbf{2}$ were eluted at 13.2 and 15.2 minutes, respectively, to give pure $\mathbf{1}(12.1 \mathrm{mg})$ and $\mathbf{2}(9.6 \mathrm{mg})$.

AR was prepared from pig lenses. Pig lenses were homogenized in $60 \mathrm{mM} \mathrm{Na}$, K-phosphate buffer ( $\mathrm{pH}$ 6.2) containing $0.5 \mathrm{mM}$ phenylmethylsulfonyl fluoride (PMSF) and $0.5 \mathrm{mM}$ 2-mercaptoethanol, and centrifuged at $100,000 \times g$ for 30 minutes. The supernatants were further purified by ammonium sulfate precipitation, and saved as enzyme fractions. All the procedures for enzyme preparation were carried out at $4^{\circ} \mathrm{C}$.

AR activity was assayed according to the method previously described by Nishikawa et al. [1] with slight modifications. The reaction mixture contained $30 \mathrm{mM} \mathrm{Na}$, K-phosphate buffer ( $\mathrm{pH}$ 6.2), $0.4 \mathrm{M} \mathrm{LiSO}_{4}, 0.125 \mathrm{mM}$ $\mathrm{NADPH}, 3 \mathrm{mM}$ DL-glyceraldehyde and proper enzyme fraction, with or without $10 \mu \mathrm{l}$ of various concentrations of 1 and 2 (dissolved in DMSO) in a total volume of $200 \mu 1$. The reaction was initiated by the addition of NADPH, the concentration change in NADPH was monitored

Table $1{ }^{1} \mathrm{H}(500 \mathrm{MHz})$ and ${ }^{13} \mathrm{C}(125 \mathrm{MHz})$ NMR spectral data of $\mathbf{1}$ and $\mathbf{2}$ in DMSO- $d_{6}$ at $25^{\circ} \mathrm{C}$

\begin{tabular}{|c|c|c|c|c|c|}
\hline \multirow{2}{*}{ Position } & \multicolumn{3}{|c|}{1} & \multicolumn{2}{|l|}{2} \\
\hline & $\delta_{\mathrm{H}}$ & $\delta_{\mathrm{C}}$ (mult) & $\mathrm{HMBC}(\mathrm{H}$ to $\mathrm{C})$ & $\delta_{\mathrm{H}}$ & $\delta_{\mathrm{C}}$ (mult) \\
\hline 2 & $8.29(1 \mathrm{H}, \mathrm{s})$ & $154.5 d$ & $C-4,9$ & $8.34(1 \mathrm{H}, \mathrm{s})$ & $153.7 \mathrm{~d}$ \\
\hline 3 & & $122.9 \mathrm{~s}$ & & & $121.9 \mathrm{~s}$ \\
\hline 4 & & $174.5 \mathrm{~s}$ & & & $179.9 \mathrm{~s}$ \\
\hline 5 & $7.95(1 \mathrm{H}, \mathrm{d}, 9)$ & $127.3 d$ & $C-4,7,9$ & & $164.0 \mathrm{~s}$ \\
\hline 6 & $6.93(1 \mathrm{H}, \mathrm{dd}, J=9,2.5)$ & $115.1 \mathrm{~d}$ & C-8, 10 & $6.22(1 \mathrm{H}, \mathrm{d}, J=2.5)$ & $99.9 d$ \\
\hline 7 & & $162.5 \mathrm{~s}$ & & & $161.8 \mathrm{~s}$ \\
\hline 8 & $6.86(1 \mathrm{H}, \mathrm{d}, J=2.5)$ & $102.0 \mathrm{~d}$ & $C-7,9$ & $6.38(1 \mathrm{H}, \mathrm{d}, J=2.5)$ & $93.4 \mathrm{~d}$ \\
\hline 9 & & $157.3 \mathrm{~s}$ & & & $157.3 \mathrm{~s}$ \\
\hline 10 & & $116.3 \mathrm{~s}$ & & & $106.7 \mathrm{~s}$ \\
\hline $5-\mathrm{OH}$ & - & & & $12.58(1 \mathrm{H}, \mathrm{s})$ & \\
\hline $7-\mathrm{OH}$ & $10.23(1 \mathrm{H}, \mathrm{s})$ & & & $10.32(1 \mathrm{H}, \mathrm{s})$ & \\
\hline $1^{\prime}$ & & $123.2 \mathrm{~s}$ & & & $123.2 \mathrm{~s}$ \\
\hline $2^{\prime}$ & $7.28(1 \mathrm{H}, \mathrm{d}, J=2)$ & $119.4 d$ & $C-1^{\prime}, 3^{\prime}, 4^{\prime}, 6^{\prime}$ & $7.28(1 \mathrm{H}, \mathrm{d}, J=2)$ & $121.5 d$ \\
\hline $3^{\prime}$ & & $143.6 \mathrm{~s}$ & & & $143.6 \mathrm{~s}$ \\
\hline $4^{\prime}$ & & $147.8 \mathrm{~s}$ & & & $147.9 \mathrm{~s}$ \\
\hline $5^{\prime}$ & $6.87(1 \mathrm{H}, \mathrm{d}, J=8.5)$ & $116.6 \mathrm{~d}$ & $C-1^{\prime}, 3^{\prime}, 4^{\prime}, 6^{\prime}$ & $6.88(1 \mathrm{H}, \mathrm{d}, J=8.5)$ & $115.9 d$ \\
\hline $6^{\prime}$ & $7.05(1 \mathrm{H}, \mathrm{dd}, J=8.5,2)$ & $123.4 d$ & $\mathrm{C}-1^{\prime}, 2^{\prime}, 4^{\prime}, 5^{\prime}$ & $7.07(1 \mathrm{H}, \mathrm{dd}, J=8.5,2)$ & $120.9 d$ \\
\hline $4^{\prime}-\mathrm{OH}$ & $9.15(1 \mathrm{H}, \mathrm{s})$ & & & $9.09(1 \mathrm{H}, \mathrm{s})$ & \\
\hline \multicolumn{6}{|l|}{ Sugar } \\
\hline 1" & $5.27(1 \mathrm{H}, \mathrm{br} \mathrm{s})$ & $99.9 d$ & $C-3^{\prime}, 2^{\prime \prime}, 3^{\prime \prime}, 5^{\prime \prime}$ & $5.27(1 \mathrm{H}, \mathrm{s})$ & $98.8 d$ \\
\hline $2^{\prime \prime}$ & $3.70(1 \mathrm{H}, \mathrm{m})$ & $70.1 d$ & & $3.64(1 \mathrm{H}, \mathrm{m})$ & $69.9 \mathrm{~d}$ \\
\hline $3^{\prime \prime}$ & $3.90(1 \mathrm{H}, \mathrm{m})$ & $70.3 d$ & & $3.90(1 \mathrm{H}, \mathrm{m})$ & $70.2 d$ \\
\hline $4^{\prime \prime}$ & $3.16(1 \mathrm{H}, \mathrm{m})$ & $71.9 d$ & & $3.14(1 \mathrm{H}, \mathrm{m})$ & $71.8 d$ \\
\hline $5^{\prime \prime}$ & $3.72(1 \mathrm{H}, \mathrm{m})$ & $69.4 d$ & & $3.75(1 \mathrm{H}, \mathrm{m})$ & $69.2 \mathrm{~d}$ \\
\hline $6^{\prime \prime}$ & $1.13(3 \mathrm{H}, \mathrm{d}, J=6.5)$ & $17.8 \mathrm{q}$ & $C-3^{\prime \prime}, 4^{\prime \prime}, 5^{\prime \prime}$ & $1.05(3 \mathrm{H}, \mathrm{d}, J=6.5)$ & $17.4 \mathrm{q}$ \\
\hline
\end{tabular}


spectrophotometrically for 1 minute at $340 \mathrm{~nm}$ using a spectrophotometer at $37^{\circ} \mathrm{C}$. As a result, 1 and 2 inhibited $\mathrm{AR}$ at the $\mathrm{IC}_{50}$ of $170 \mu \mathrm{M}$ and $165 \mu \mathrm{M}$, respectively.

Compound 1 was obtained as a pale yellow solid with $\mathrm{UV}(\mathrm{MeOH}) \lambda_{\max } 249$ and $320(\mathrm{sh}) \mathrm{nm}$, and its formula was established as $\mathrm{C}_{21} \mathrm{H}_{20} \mathrm{O}_{9}$ by HRFAB-MS $m / z 417.1194$ $[\mathrm{M}+\mathrm{H}]^{+}$, Calculated for 417.1185 . The ${ }^{1} \mathrm{H}$ and ${ }^{13} \mathrm{C}$ NMR spectra revealed that $\mathbf{1}$ was an isoflavonoid with glycosidic functionalities present (Table 1). The ABX spin system in ${ }^{1} \mathrm{H}$ NMR $\delta 7.95(1 \mathrm{H}, \mathrm{d}, J=9 \mathrm{~Hz}), 6.93(1 \mathrm{H}, \mathrm{dd}, J=9$, $2.5 \mathrm{~Hz})$ and $6.86(1 \mathrm{H}, \mathrm{d}, J=2.5 \mathrm{~Hz})$, which correlated to carbons at $\delta 127.3,115.1,102.0$ in the HMQC, were characteristic of $\mathrm{H}-5, \mathrm{H}-6, \mathrm{H}-8$ protons of the A ring and the other three signals in ${ }^{1} \mathrm{H}$ NMR $\delta 7.28(1 \mathrm{H}, \mathrm{d}, J=2 \mathrm{~Hz})$, $6.87(1 \mathrm{H}, \mathrm{d}, J=8.5 \mathrm{~Hz})$ and $7.05(1 \mathrm{H}, \mathrm{dd}, J=8.5,2 \mathrm{~Hz})$, which correlated to carbons at $\delta 119.4,116.6,123.4$ in the HMQC, were assigned to H-2', H-5' and H-6' protons of the $\mathrm{B}$ ring of $\mathbf{1}$, respectively. Moreover, one proton broad singlet at $\delta 5.27$ with very small $J$ values and a set of threeproton doublets $(J=6.5 \mathrm{~Hz})$ at $\delta 1.13$ were presented. These facts suggested the presence of a deoxysugar with a $\alpha$ configuration because of the very low $J$ values of its anomeric protons due to trans-diequatorial interactions. Analysis of the ${ }^{13} \mathrm{C}$ NMR spectrum confirmed the identity of the sugar as rhamnose. In HMBC spectra, strong correlations from $\mathrm{H}-1^{\prime \prime}\left(\delta\right.$ 5.27) to $\delta 143.6\left(\mathrm{C}-3^{\prime}\right)$ (three bonds correlation) and relative weak correlations from $\mathrm{H}-2^{\prime}$

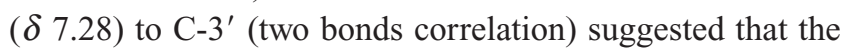
rhamnose group was located at C-3'. Acid hydrolysis of $\mathbf{1}$ liberated L-rhamnose, identified by TLC with authentic samples. Therefore 1 is 7,4'-dihydroxyisoflavone $3^{\prime}-O-\alpha$-Lrhamnopyranoside (daidzein $3^{\prime}-O-\alpha$-L-rhamnopyranoside).

Compound 2 was obtained as a pale yellow solid with $\mathrm{UV}(\mathrm{MeOH}) \lambda_{\max } 260$ and $320(\mathrm{sh}) \mathrm{nm}$, and its molecular formula was confirmed as $\mathrm{C}_{21} \mathrm{H}_{20} \mathrm{O}_{10}$ from HRFAB-MS $\mathrm{m} / \mathrm{z}$ 433.1156 $[\mathrm{M}+\mathrm{H}]^{+}$, Calculated for 433.1134. NMR and other spectroscopic data were nearly identical with those of 1 (Table 1). The only difference was that two meta-coupled doublets at $\delta 6.22(1 \mathrm{H}, \mathrm{d}, J=2.5 \mathrm{~Hz})$ and $6.38(1 \mathrm{H}, \mathrm{d}$, $J=2.5 \mathrm{~Hz}$ ), which correlated to carbons at $\delta 99.9$ and 93.4 ppm in the HMQC, were characteristic of H-6, and H-8 protons of A ring. In conclusion, the structure of 2 was elucidated as $5,7,4^{\prime}$-trihydroxyisoflavone $\quad 3^{\prime}-O-\alpha-\mathrm{L}-$ rhamnopyranoside (genistein $3{ }^{\prime}-O-\alpha$-L-rhamnopyranoside).

Compounds $\mathbf{1}$ and $\mathbf{2}$ were isolated only from the fermentation broth of Streptomyces diannanensis which was cultured with medium containing soybean meal (data not shown), but the two compounds could not been obtained from the uninoculated soybean meal. This suggested that both soybean meal and Streptomyces diannanensis are necessary for the production of these two compounds.

Although some novel isoflavones and isoflavone glucosides have been isolated from actinomycetes, especially from Streptomyces [6 9], only Hu et al. [6] and Hazato et al. [7] reported the production of isoflavone rhamnopyranosides from microorganisms. Novel compounds N99-596 A and B which belong to isofalvone rhamnopyranosides are rare microbial metabolites as far as we know.

\section{References}

1. Nishikawa M, Tsurumi Y, Namiki T, Yoshida K, Okuhara M. Studies on WF-3681, a novel aldose reductase inhibitor I. Taxonomy, fermentation, isolation and characterization. J Antibiot 40: 1394-1399 (1987)

2. Rao KCS, Divakar S, Srinivas M, Babu KN, Karanth NG, Sattur AP. Asperaldin, a new aldose reductase inhibitor from Aspergillus niger CFR-1046. I. Fermentation, isolation and characterization. J Antibiot 56: 173-176 (2003)

3. Rao KCS, Divakar S, Babu KN, Rao AGA, Karanth NG, Sattur AP. Nigerloxin, a novel inhibitor of aldose reductase and lipoxygenase with free radical scavenging activity from Aspergillus niger CFR-W-105. J Antibiot 55: 789-793 (2002)

4. Dvornik E, Simard-Duquesne N, Krami M, Sestanj K, Gabbay KH, Kinoshita JH, Varma SD, Merola LO. Polyol accumulation in galactosemic and diabetic rats: control by an aldose reductase inhibitor. Science 182: 1146-1148 (1973)

5. Nakamura N, Yamazaki K, Satoh A, Urakaze M, Kobayashi M, Yamabe H, Osawa H, Shirato K, Sugawara T, Nakamura M, Tamura M, Okumura K. Effects of eparlestat on plasma levels of advanced glycation end products in patients with type 2 diabetes. In Vivo 17: 177-180 (2003)

6. Hu JF, Wunderlich D, Sattler I, Thiericke R, Grabley S, Feng XZ. New 2-O-methylrhamno-isoflavones from Streptomyces sp. Nat Prod Res 17: 451-458 (2003)

7. Hazato T, Naganawa H, Kumagai M, Aoyagi T, Umezawa H. $\beta$-Galactosidase-inhibiting new isoflavonoids produced by actinomycetes. J Antibiot 32: 217-222 (1979)

8. Umezawa H, Tobe H, Shibamoto N, Nakamura F, Nakamura $\mathrm{K}$, Matsuzaki M, Takeuchi T. Isolation of isoflavones inhibiting DOPA decarboxylase from fungi and Streptomyces. J Antibiot 28: 947-952 (1975)

9. Komiyama K, Funayama S, Anraku Y, Mita A, Takahashi Y, Omura S, Shimasaki H. Isolation of isoflavonoids possessing antioxidant activity from the fermentation broth of Streptomyces sp. J Antibiot 42: 1344-1349 (1989) 